\title{
WEB-APPLICATION FOR ARCHIVING OF CREEP AND LONG TERM STRENGTH DATA
}

The paper is devoted to description of the software, which made as web-application, for collection, storing and processing the data of creep and long term strength, including the case of creep-fatigue interaction. The short review and analysis of problem is presented. The technology for minimization of creep data storing as well as the architecture of web-application is discussed. Software contains the possibility of imaging three parts of data, which are creep curves, long term strength curves and diagrams of limiting amplitudes and stresses. The values of temperature, stress, grade and literature reference to the data are demanded database fields. The examples of the work with database and with plots are presented.

Keywords: creep, long term strength, creep-fatigue interaction, experimental results, web-application, material data storing.

Introduction. Preserving of information containing the experimental test data is very important problem. The last century was characterized by the snowballing increasing of publications in different handbooks, monographs and papers in scientific journals, in which the manifold results of experiments were published. Nonlinear Mechanics demands a number of experiments, which is a lot more then in traditional part of Mechanics. Due to their timedependent character the creep and long term strength experiments present one of the most labor- and time consuming part of the experimental investigations in Mechanics. The creep experimental data were scattered in a lot of papers and monographs, among which the books [1-5] can be specially mentioned. The review of publications made in Russian up to end of $80^{\text {th }}$ years of XX century can be find in the book of Nikitenko and Vakulenko [6], as well as the last review in this field was published in the paper of Mackerle. [7]. But the largest amount of the data contains in a scientific journal papers.

In a time, the unique experimental data became unavailable because of natural causes which firstly include the practical impossibility for the researcher to recognize the source of information with necessary knowledge. So, the large amount of experimental results remains unknown for scientist or engineer who needs the corresponding data. Such situation leads to repeating of experiments which demand a lot of time and costs.

This problem is deepened in the case of long term experiments which are necessary in investigations of creep, especially it concerns to the tests which are carried up to the rupture of specimens. The costs here are increased many times due to time dependence of this type of experiments.

The first attempt for solving of the problem in consideration was the digitizing of publications. The creating of big electronic libraries benefits the many investigations, but the problem doesn't solve finally: it is practically impossible to find the data for necessary grades with demanding values of temperatures, stresses and other test conditions by use only the title or abstract of a paper.

One way of the problem's solution, which is most general in last decades, is developing of databases containing the full set of possibilities for data collection, storage and processing. Now the best way to access the databases is installation them in Internet as a web-application.

This possibility for more common data of chemical composition, physical, mechanical and technological properties of engineering materials was realized in a few web-portals. Among them the MatWeb (http://www.matweb.com), Databook of Steels and Alloys (http://www.splav-kharkov.com) [8], which contains the data of grades due to former Soviet standards, and European Steels and Alloys (http://www.steelnumber.com), can be marked for their completeness and availability.

It is necessary to mark that creep and long term strength data are practically absent in this web-sites. Only some examples of coefficients for equation describing the uniaxial creep by Norton law jointly with RabotnovKachanov damage model [1] can be found in Databook of Steels and Alloys [8], but information about experimental creep and long term strength curves are absent therein.

Thereby the development of new database containing information of creep experimental data including representation of creep curves with primary, secondary and tertiary curve pieces, long term strength curves as well as amplitude diagrams for creep-fatigue tests, can be regarded as an important task.

Software description. The presented paper is devoted to description of the implementation of this goal as web-application 'CREEP DATA' with access to database of creep experimental results. It is designed as a part of web-portal 'The World of Mechanics' (http://www.worldmech.net), where the information about achievements in different fields of Mechanics is planned to be loaded.

The work has two stages. The first one consists in development of database architecture, its implementation into the server, design of the web-site pages with appropriate interface sections and data completion. After the moment when the database of creep data will be initially completed, the second part, which include development of special software for analysis of data sorting, automatic deriving of creep-damage equation coefficients etc, has to be done. Just now the first part is completed and will be presented in a paper.

Let us discuss our strategy. The creep curve plots are usually presented as a bitmap figures in scientific papers or books. From the point of view of data processing such presentation is not convenient for storing both due to large dimension of each image and to practical hardness of direct access to data.

That is why another approach has been suggested. The knowledge of creep curve behavior, which generally demonstrates three above mentioned pieces, allows us to 
formalize it. Only few points from creep curve are necessary for storing the data. Two-dimensional creep curve plot is built by two coordinates, which are time $t$ and creep strain $c$ values. The schematic representation of this partitioning is presented on Fig.1.

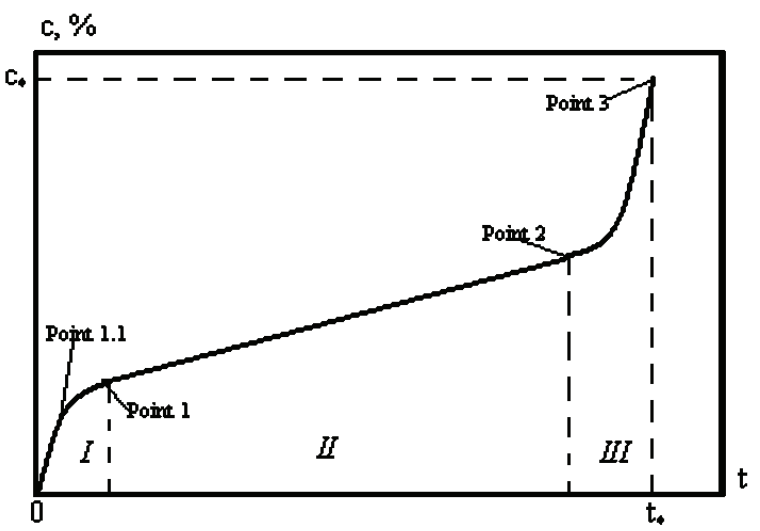

Figure 1 - Schematic representation of creep curve

Due to the fact that $c(0)=0$, the Point 1 is the point of approximate dissection between primary and secondary creep, Point 2 is the point of approximate dissection between secondary and tertiary creep, and Point 3 coincides to the moment of specimen's rupture.

Of course, we can include to the storage the curves, in which one or two creep stages are absent. Point 1.1 was additionally introduced in order to obtain the possibility of deriving the analytical expression for primary creep. So, each creep curve needs maximum four pairs of numbers for its formal representation.

The input data allows the graphical imaging. The simplified presentation of primary and tertiary creep stages by Bezier curves is used [9]. Of course, some distinctions with real curve take place, but this image is necessary only for visual control of data has been input by user.

Now let us briefly discuss the working sequence. The user who intends filling some database fields has to register in site. The page http://worldmech.net/creep/ contains the necessary form for registration. After successful login the user has to select 'Add form' (Fig. 2) in the page where the selection of actions with different creep data is suggested. Further the information about existing points in creep curve as well as another data consists of stress and temperature value, steel grade and reference to the publication in which this plot is presented has to be added in forms.

The information which was sent to server is checked by database manager. In the case of correct checking the data are available in the web-page. User can browse the creep curve plot by use the form 'Look graphics'. Fig 3 contains the example of the plot construction for steel G91 at $T=873 \mathrm{~K}$ and stress $160 \mathrm{MPa}[10]$.

The similar approach is used for the representation of two another phenomena is connected with creep process in solids. They are long term strength and data of strength due to joint action of creep and fatigue (so-called diagrams of limiting amplitudes and stresses). The form which is necessary to be filled for representation of creep long strength data includes three points which described two pieces of curve. The first stage represents ductile part of the curve as well as the brittle one represents by the second. Each point has two coordinates: time and stress values. The logarithmic scale is used.

Figure 4 contains an example of such curve for steel S590 at $T=921 \mathrm{~K}[11]$.

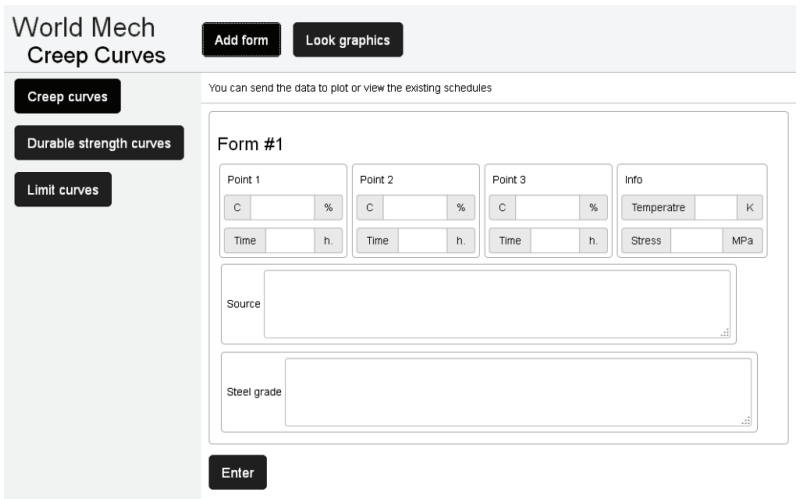

Figure 2 - Form for adding of creep data

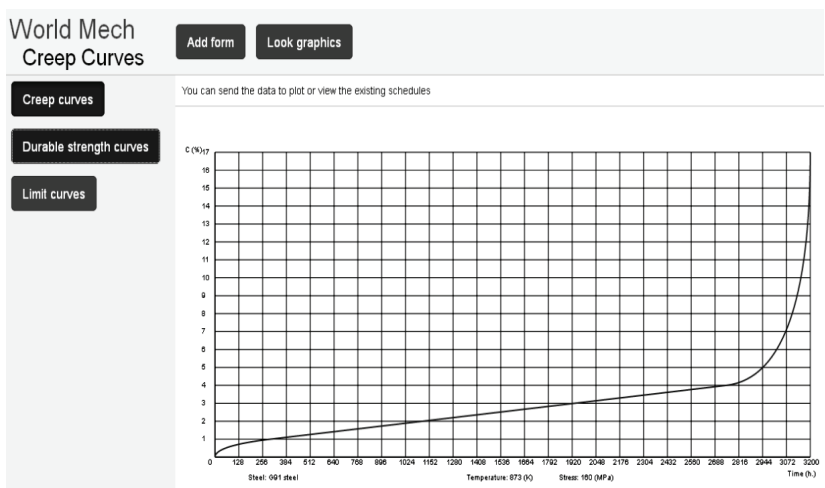

Figure 3 - Presentation of creep curve

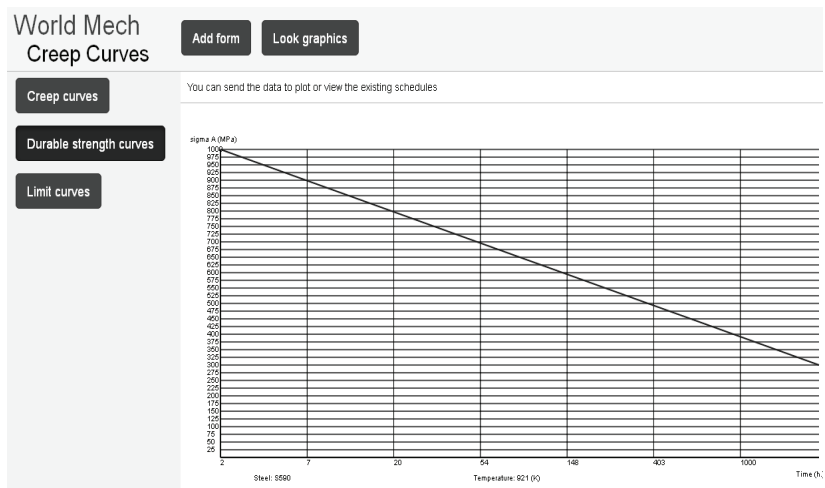

Figure 4 - Presentation of long term strength law

The third form uses for input of experimental results which represent the data set characterizing the fracture of specimen. Coordinates here are mean and amplitude stresses which combination brings to fracture at the same time. The user has to be filled these data in an array with two columns.

Let us present in Fig. 5 an example of the limit curve built for high temperature nickel based alloy EI867 at $T=1173 \mathrm{~K}$ with equal fracture time $600 \mathrm{~h}$ [12]. In current version the points in diagram are connected by straight lines. 


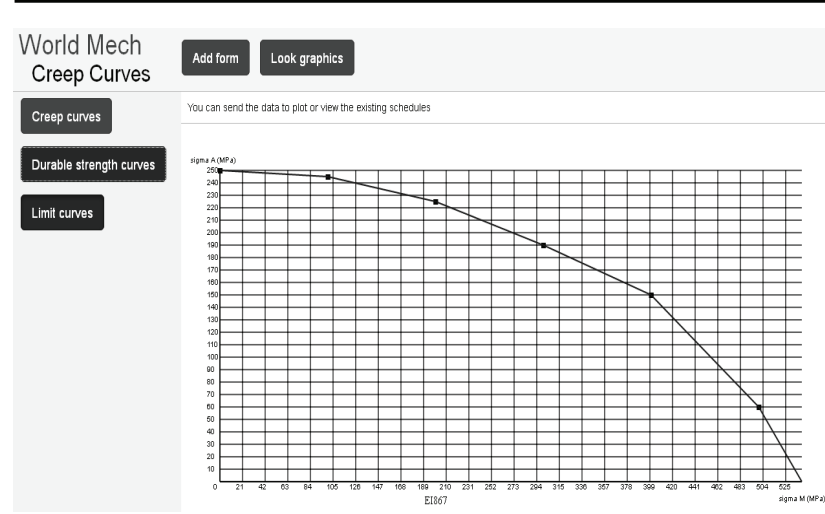

Figure 5 - Presentation of diagrams of limiting amplitudes and stresses

Both forms demand temperature value, steel or alloy grade and reference to the publication in a literature.

So, after filling the base users will obtain the possibility to implement both separate data and creep-damage equations in their numerical analysis of high temperature behavior of structural members.

Software features. Let us briefly describe the developed technology. Data-query language SQL [13] is used in order to form and work with the database.

All numerical analysis in application is written on JavaScript language [14]. Calculations for plots building, user's and administrator's interfaces structure are run in JSe. PHP language uses only for the connection of scripts with the database and for user's authorization.

Plots are built by use of Canvas technology [14]. It is available in HTML5 and now is often used for bitmap image creation by use of scripts which are written in JavaScript language. Using Canvas we not need to load the bitmap image from server, because by use of developed algorithms the picture is created in a browser immediately. Canvas contains the large amount of graphical tools including Bezier curves building.

All necessary information from database is obtained by use of AJAX (Asynchronous Javascript And Xml), which is the technology allows the data exchange without full page reloading [14]. Its use allows to reduce the server's duty cycle by obtaining in each moment only necessary information.

One of the main advantages of the developed webbased application is that information is not stored in readonly text files, but in a special database allowing the user to select a particular characteristic exactly or in the given range. Interface is a standard for web-programming, all of actions are available from the site menu, located at the page.

For user's session the personal computer with any Internet browser and Internet access is necessary.

Conclusions. The description of specialized webapplication 'Creep Data' developed for storing, quick access and processing of the creep and long term strength data of modern structural metallic materials is presented. The web-application's possibilities for engineers and scientists in Mechanical Engineering and Solid Mechanics are discussed.
Bibliography: 1. Lemaitre J. Mechanics of solid materials / J. Lemaitre, J.-L. Chaboche. - Cambridge: University press, 1994. - $556 \mathrm{p}$. 2. Penny R. K. Design for creep / R. K. Penny, D. L. Marriot. - London: Chapmann and Hall, 1995. - 430 p. 3. Rabotnov Yu. N. Creep Problems in Structural Members / Yu. N. Rabotnov. - Amsterdam/London: NorthHolland Publishing, 1969. - 822 p. 4. Viswanathan R. Damage mechanics and life assessment of high temperature components / R. Viswanathan. - ASM International, 1989. - 497 p. 5. Шестериков С. А. Закономерности ползучести и длительной прочности: $\quad$ Справочник / C. А. Шестериков. М.: Машиностроение, 1983. - 101 с. 6. Никитенко А. Ф. Ползучесть и длительная прочность элементов конструкций. Библиографический указатель отечественной и зарубежной литературы за 19701985 гг. / А. Ф. Никитенко, Л. Д. Вакуленко. - Новосибирск: Ин-т гидродинамики им. М. А. Лаврентьева, 1987. - 341 с. 7. Mackerle J. Creep and creep fracture/damage finite element modelling of engineering materials and structures: An addendum / J. Mackerle // International Journal of Pressure Vessels and Piping. - 2004. - Vol. 81, № 5. - P. 381392. 8. Breslavskaya E. A. Internet-portal «Database of Steels and Alloys» as an efficient tool in engineering/ E. A. Breslavskaya, D. V. Breslavsky // CIS Iron \& Steel Review 2011. - 2011. - № 1.P. 12-15. 9. Joon Ahn Young Approximation of circular arcs and offset curves by Bézier curves of high degree / Ahn Young Joon // Journal of Computational and Applied Mathematics. - 2004. - Vol. 167, № 2. P. 405-416. 10. Kim Woo-Gon Long-Term Creep Characterization of Gr. 91 Steel by Modified Creep Constitutive Equations/Woo-Gon Kim, Sung-Ho Kim, Chan-Block Lee // Metals and Materials International. 2011. - Vol. 17, № 3. - P. 497-504. 11. Маньковский В. А. Прогнозирование длительной прочности конструкционных сталей и сплавов / В. А. Маньковский, В. Т. Сапунов // Заводская лаборатория Диагностика материалов. - 2006. - № 7. - С. 41-45. 12. Голуб В. П. Циклическая ползучесть жаропрочных никелевых сплавов / В. П. Голуб. - Киев: Наукова думка, 1983. - 224 с. 13. Кригель $A$. SQL. Библиотека пользователя / A. Кригель, Б. Трухнов. - М: Диалектика, 2009. - 752 c. 14. Chapman N. Digital Multimedia 2nd edition / N. Chapman, J. Chapman. - John Wiley \& Sons, 2004. - 698 c.

Bibliography (transliterated): 1. Lemaitre, J. and J.-L. Chaboche. Mechanics of solid materials. Cambridge: University press, 1994. Print. 2. Penny, R. K. and D. L. Marriot. Design for creep. London: Chapmann and Hall, 1995. Print. 3. Rabotnov, Yu. N. Creep Problems in Structural Members. Amsterdam/London: North-Holland Publishing, 1969. Print. 4. Viswanathan, R. Damage mechanics and life assessment of high temperature components. ASM International, 1989. Print. 5. Shesterikov, S. A. Zakonomernosti polzuchesti i dlitel'noj prochnosti: Spravochnik. Moskow: Mashinostroenie, 1983. Print. 6. Nikitenko, A. F. and L. D. Vakulenko. Polzuchest' i dlitel'naja prochnost' jelementov konstrukcij. Bibliograficheskij ukazatel' otechestvennoj i zarubezhnoj literatury za 1970-1985 gg. Novosibirsk: In-t gidrodinamiki im. M. A. Lavrent'eva, 1987. Print. 7. Mackerle, J. "Creep and creep fracture/damage finite element modelling of engineering materials and structures: An addendum". International Journal of Pressure Vessels and Piping 81.5 (2004): 381-392. Print. 8. Breslavskaya, E. A. and D. V. Breslavsky. "Internet-portal «Database of Steels and Alloys» as an efficient tool in engineering". CIS Iron \& Steel Review 20111 (2011): 12-15. Print. 9. Joon, Ahn Young. "Approximation of circular arcs and offset curves by Bézier curves of high degree". Journal of Computational and Applied Mathematics 167.2 (2004): 405-416. Print. 10. Kim, Woo-Gon, Sung-Ho Kim and Chan-Block Lee. "LongTerm Creep Characterization of Gr. 91 Steel by Modified Creep Constitutive Equations". Metals and Materials International 17.3 (2011): 497-504. Print. 11. Man'kovskij, V. A. and V. T. Sapunov. "Prognozirovanie dlitel'noj prochnosti konstrukcionnyh stalej i splavov". Zavodskaja laboratorija. Diagnostika materialov. 7 (2006): 41 45. Print. 12. Golub, V. P. Ciklicheskaja polzuchest' zharoprochnyh nikelevyh splavov. Kiev: Naukova dumka, 1983. Print. 13. Krigel, A. and B. Truhnov. SQL. Biblioteka pol'zovatelja. Moskow: Dialektika, 2009. Print. 14. Chapman, N. and J. Chapman. Digital Multimedia 2nd edition. John Wiley \& Sons, 2004. Print.

Надійшла (received) 21.12.2015 
Відомості про авторів / Сведения об авторах / About the Authors

Бреславський Дмитро Васильович - доктор технічних наук, професор, завідувач кафедри систем і процесів управління, Національний технічний університет «ХПІ»; тел.: (057)-707-64-54; e-mail: brdm@kpi.kharkov.ua.

Breslavsky Dmytro Vasylovych - Doctor of Technical Sciences, Professor, Head of the Department of Control Systems and Processes, National Technical University "KhPI"; tel.: (057)-707-64-54; e-mail: brdm@kpi.kharkov.ua.

Бреславська Олена Олександрівна - кандидат технічних наук, науковий співробітник кафедри теоретичної механіки, Національний технічний університет «ХПІ»; тел.: (057)-707-63-73; e-mail: breslavska@ukr.net.

Breslavska Olena Oleksandivna - Candidate of Technical Sciences, Research Associate of the Department of Theoretical Mechanics, National Technical University "KhPI"; tel.: (057)-707-63-73; e-mail: breslavska@ukr.net.

Хорошун Андрій Серхійович - магістр з інформатики, web-розробник у компанії SKALAR; тел.: (057)-707-64-54; e-mail: a.s.khoroshun@gmail.com.

Khoroshun Andriy Sergiyovych - Master of Informatics, Web-developer of the company SKALAR; tel.: (057) 707-64-54; e mail: a.s.khoroshun@gmail.com.

\section{УДК 539.3}

\section{Д. В. БРЕСЛАВСЬКИЙ, В. М. КОНКІН, В. О. МЕТЕЛЬОВ}

\section{ПЛАСТИЧНІСТЬ ТА ПОВЗУЧІСТЬ СТАЛІ 3 ПРИ КІМНАТНІЙ ТЕМПЕРАТУРІ}

В статті наведено отримані авторами експериментальні результати з деформування зразків зі сталі 3 при кімнатній температурі й напруженнях, що перевершують межу міцності. Обговорюються рівняння стану, що можуть бути застосовані для опису деформування цієї сталі за часом. Виявлено істотну анізотропію властивостей повзучості. Порівняння даних, отриманих розрахунками, з експериментальними показало задовільну можливість використання запропонованих рівнянь.

Ключові слова: пластичність, повзучість, рівняння стану, криві повзучості, анізотропія властивостей повзучості, прокатка, експериментальні дослідження, плоскі зразки.

Вступ. Деформування матеріалів за межами пружності призводить до виникнення незворотних деформацій. Зазвичай вони розподіляються на миттєві деформації пластичності та деформації повзучості, що залежать від часу. Як відмічають Ж. Леметр та Ж.-Л. Шабош [1], для більшості металів деформації повзучості є суттєвими при температурі $T>T_{n \pi} / 3$, де $T_{n л}-$ температура плавлення, однак існують метали, що виявлять властивості повзучості й при кімнатній температурі $T=300 \mathrm{~K}$, навіть якщо $T_{n л}=1400 \mathrm{~K}$. Часто деформації повзучості виникають на тлі миттєвих пластичних деформацій. При цьому часто рівень напружень є досить високим, що призводить до дуже швидкого руйнування матеріалу. У цьому випадку таке явище носить назву короткочасної повзучості $[2,3]$.

Особливо важливим $є$ аналіз рівня деформацій повзучості, які є короткочасними, при розрахунках технологічних процесів, наприклад прокатки, волочіння тощо, у зв'язку з необхідністю точного визначення розмірів листових заготівок та їхнього напружено-деформованого стану у будь-який момент часу $[4,5]$. Розрахункове оцінювання незворотних деформацій потребує формулювання відповідних рівнянь стану та проведення експериментальних досліджень для визначення значень констант, що до них входять.

Для опису плину матеріалу при складному напруженому стані найкращі результати як в теорії повзучості, так й в теорії пластичності надають теорії інкрементального типу [6-9]. При аналізі деформування листових матеріалів, отриманих прокаткою, часто встановлюють ортотропію залежностей деформацій чи їхніх швидкостей від напружень. У цьому випадку застосовують спеціальні форми визначальних співвідношень, що їі враховують [1, 7, 10-12].

Дану статтю присвячено дослідженню деформування Сталі 3 при кімнатній температурі. Надано опис методики експериментів при простому напруженому стані. Наведено отримані експериментальні результати: діаграми деформування зразків, криві повзучості зразків, що були вирізані в трьох напрямках з листового матеріалу. Запропоновано рівняння стану, які враховують присутність складових, викликаних миттєвою пластичністю та повзучістю матеріалу, та отримано значення констант, що до них входять.

Експериментальні дослідження плоских зразків. В роботі виконано дослідження деформування зразків зі Сталі 3. Для всіх експериментів було використано сталеві листи однієї партії постачання. Було проведено дві групи експериментів: зняття кривих деформування для встановлення залежності «напруження-деформація» при одновісному розтягу; отримання залежності повної деформації зразків від часу. Всі дослідження було виконано при нормальній температурі 293 К.

Для зняття діаграми деформування зразків з листового матеріалу було вирізано по три зразки: вздовж, поперек напряму прокатки та під кутом $45^{\circ}$ до нього. Зразки виготовлялись фрезеруванням за вимогами ДСТУ 3248-81. До експериментів було залучено ви- 